\title{
QUANTIFICATION OF HYALURONIC ACID AND METHYLSULFONYLMETHANE IN DIETARY SUPPLEMENTS
}

\author{
HARMITA HARMITA*, HAYUN HAYUN, M. HERU GEOFANI
}

Department of Pharmacy, Faculty of Pharmacy, Universitas Indonesia, Depok, Indonesia. Email: igakadeharmita@gmail.com Received: 26 September 2019, Revised and Accepted: 17 December 2019

ABSTRACT

Objective: Osteoarthritis can be treated by taking oral supplements containing compounds that can nourish bones and joints such as hyaluronic acid, methylsulfonylmethane (MSM), chondroitin, glucosamine, and collagen. This study aimed to develop and validate tests for analyzing two compounds, namely, hyaluronic acid and MSM, simultaneously and to determine both their levels in a mixed sample.

Methods: Hyaluronic acid derivatization was carried out using fluorenylmethyloxycarbonyl chloride and then analyzed by liquid chromatography with fluorescence detection, while MSM was analyzed using gas chromatography. After the development of optimal conditions for each separation, system suitability tests were developed and calibration curves used for tests of accuracy and precision as well as for level determination. Hyaluronic was detected at an excitation wavelength of $255 \mathrm{~nm}$ and emission wavelength of $330 \mathrm{~nm}$. The mobile phase used was acetonitrile-acetate pH 4.2 (1: 4) with a flow rate of $1.0 \mathrm{~mL} / \mathrm{min}$.

Results: The developed method was linear ( $\mathrm{r}=0.9983$ ) in the range of 5-50 ppm and the limits of detection (LOD) and quantitation (LOQ) were 3.55 and $11.84 \mathrm{ppm}$, respectively. The initial column temperature for MSM analysis was $110^{\circ} \mathrm{C}$ and the mobile phase used was nitrogen gas at a flow rate of $0.8 \mathrm{~mL} / \mathrm{min}$. The method was linear $(\mathrm{r}=0.9998)$ in the range of 4000-15,000 ppm and the LOD and LOQ were 332.90 and $1109.67 \mathrm{ppm}$, respectively.

Conclusion: A simulated sample containing both compounds was assessed to contained 98.63\% hyaluronic acid and 99.35\% MSM.

Keywords: Hyaluronic acid, Methylsulfonylmethane, High-performance liquid chromatography, Gas chromatography, Fluorenylmethyloxycarbonyl chloride, Component, Optimization, Validation.

(C) 2020 The Authors. Published by Innovare Academic Sciences Pvt Ltd. This is an open access article under the CC BY license (http://creativecommons. org/licenses/by/4. 0/) DOI: http://dx.doi.org/10.22159/ijap.2020.v12s1.FF032

\section{INTRODUCTION}

Food supplements are products that contain nutrients and excipients and are available as capsules, tablets, powders, or liquids; they are used in cases where dietary insufficiency of their ingredients can lead to ill health [1]. Food supplements are only complementary, and not intended to be used as substitutes for a normal diet. These supplements usually contain chemical compounds that function as nutrients in the body and they can aid in supplying the specific nutritional needs of those with certain health conditions. For example, protein supplementation is used to prevent joint pain and help tighten the skin [2]

Two compounds that are often used in supplements to prevent these conditions are hyaluronic acid and methylsulfonylmethane (MSM), both of which can nourish bones and joints [1]. There are a number such supplement products sold to treat the symptoms of osteoarthritis and these usually contain glucosamine sulfate, chondroitin sulfate, MSM, Celadrin, nattokinase, hyaluronic acid, black catechu, skullcap, Boswellia serrata, and curcumin [3]. This study developed analytical methods for only hyaluronic acid and MSM because separation all these components require high-performance gradient liquid chromatography, while only isocratic high-performance liquid chromatography (HPLC) was available.

Hyaluronic acid exists in various molecular sizes in biological tissues and fluids and can be degraded by both normal physiological or pathological conditions [4]. It consists of linear macromolecular chains of repeated glucuronic acid and N-acetyl-D-glucosamine subunits that form glucosamine when hydrolyzed [5]. Hyaluronic acid molecules of different weights have different rheological and biological properties, and this, coupled to its intrinsic biocompatibility and viscoelastic physical character, means that it has been used as a treatment for osteoarthritis [6]. Thus, hyaluronic acid is commonly used as a supplement to maintain joint health and to control tissue hydration [7].
Methylsulfonylmethane is an organosulfur compound that is commonly used as a food supplement for the prevention of metabolic diseases since the amount of MSM and sulfur in the body decreases with age [8].

Hyaluronic acid does not contain any chromophores but can be derivatized with fluorescent compounds. Reagents that are often used for such derivatization before analysis include orthophtalaldehyde, phenyl isothiocyanate (PITC), and 9-fluorenylmetoxycarbonyl chloride [3]

Hyaluronic acid has previously been analyzed are using highperformance size-exclusion liquid chromatography [9], while a study using HPLC conducted by Harmita (2015) used a silica phase with phosphoric and potassium hydroxide in conjunction with UV detectors. Methylsulfonylmethane can be analyzed by gas chromatography (GC), with the $39^{\text {th }}$ edition of the United States Pharmacopeia Edition 39 providing a method using dimethylpolysiloxane gum columns with a mobile phase of helium gas and flame ionization detection.

Here, we conducted an analysis of a mixture of hyaluronic acid and methylsulfonylmethane using HPLC in dimethyl sulfoxide with fluorescence detection for hyaluronic acid, and GC with flame ionization detection for methylsulfonylmethane analysis. Hyaluronic acid was derivatized with 9-fluoroenylmetoxycarbonil chloride, which was chosen because it can react with primary and secondary amine groups.

\section{MATERIALS AND METHODS}

\section{Materials}

Chemicals were purchased from the following suppliers: Hyaluronic acid standard (Sigma-Aldrich); methylsulfonylmethane standard (Merck); magnesium stearate (Merck); Amylum Oryzae (Merck); 9-fluoroenilmetoxicarbonyl chloride (Merck); glacial acetic acid (Merck); chloride acid (Merck); methanol pro HPLC (Merck); aqua pro 
injection (Ikapharmindo Putramas); aquadest (Brataco); acetonitrile pro HPLC (Merck); NaOH (Merck); boric acid (Merck); anhydrous sodium acetate (Merck); nitrogen (Merck); and hydrogen (Merck).

\section{Equipment}

The HPLC $\left(\right.$ Shimadzu ${ }^{\circledR}$ ) consisted of pumps, Shimadzu ${ }^{\circledR}$ C18 columns, RF 20A fluorescence detectors, manual injectors, a computer data processor, and HPLC syringes (SGE ${ }^{\circledR}$, Australia). A Shimadzu ${ }^{\circledR}$ GC model GC-17A equipped with flame ionization detector, a capillary column with a length of $30 \mathrm{~m}$, inner diameter of $0.53 \mathrm{~mm}$, and film thickness of $5 \mu \mathrm{m}$ with stationary phase G2 was used with a $10 \mu \mathrm{l}$ micro-syringe (Hamilton Co.Nevada ${ }^{\circledR}$ )

\section{Procedures}

Standard hyaluronic acid solution

Two hundred milligrams of hyaluronic acid standard was dissolved in $100 \mathrm{~mL}$ of $0.1 \mathrm{~N} \mathrm{HCl}$ and diluted to a concentration of $10 \mu \mathrm{g} / \mathrm{mL}$

\section{Standard methylsulfonylmethane solution}

Four milligrams of methylsulfonylmethane was dissolved in $1 \mathrm{~mL}$ of methanol, sonicated at $50^{\circ} \mathrm{C}$ for $1 \mathrm{~min}$, and cooled to room temperature.

\section{Wavelength optimization}

The hyaluronic acid standard ( $300 \mu \mathrm{L}$ ) was pipetted into a test tube and $300 \mu$ l of borate buffer and $300 \mu \mathrm{L}$ of $1.5 \mathrm{mM}$ fluorenylmethyloxycarbonyl chloride (FMOC-Cl) reagent added. The mixture was vortexed for $20 \mathrm{~s}$ and allowed to stand for $2 \mathrm{~min}$ before injection of $20 \mu \mathrm{L}$ into the HPLC to determine the excitation and emission wavelengths. This was achieved by varying excitation wavelengths at $255 \mathrm{~nm}$ and using three emission wavelengths $(320,325$, and $330 \mathrm{~nm})$. The selected wavelengths were those that produced the largest peak area.

\section{Determination of optimal analytic conditions}

A standard solution of hyaluronic acid with a concentration of $50 \mu \mathrm{L} / \mathrm{mL}$ as much as $100 \mu \mathrm{L}$ each into the test tube add $100 \mu$ lof borate buffer $\mathrm{pH}$ 9.3, the solution is then added FMOC-Cl reagent to the selected volume. The mixture was vortexed for $20 \mathrm{~s}$ and allowed to react before HPLC analysis. Twenty microliter aliquots were analyzed using various combinations of the mobile phase of acetate $(\mathrm{pH} 4.2)$-acetonitrile at $1: 2$, $2: 3$, and $1: 4$ and with different flow rates of $0.8,1.0$, or $1.2 \mathrm{~mL} / \mathrm{min}$.

One microliter of a standard solution of methylsulfonylmethane at a concentration of $4000 \mathrm{ppm}$ was injected into the GC, and determination of optimal analysis conditions was performed by programing various initial column temperatures of the $100^{\circ} \mathrm{C}, 110^{\circ} \mathrm{C}$, or $120^{\circ} \mathrm{C}$ and various flow rates of $0.8,1.0$, or $1.2 \mathrm{~mL} / \mathrm{min}$. The initial temperature was increased by $1^{\circ} \mathrm{C} / \mathrm{min}$ to $250^{\circ} \mathrm{C}$ and the injector and detector temperatures were set to $250^{\circ} \mathrm{C}$. The retention time, area, follow-up factor, number of theoretical plates, column efficiency (HETP), and resolution were determined for each condition, and the one that had the shortest retention time, the largest number of theoretical plates $(\mathrm{N})$, the smallest HETP, the smallest follow-up factor (Tf), and the best separation with a resolution of 1.5 or more was selected.

\section{Precision of the hyaluronic acid system}

One hundred microliters of standard solution of hyaluronic acid with a concentration of $20 \mu \mathrm{L} / \mathrm{mL}$ was added to $100 \mu \mathrm{L}$ borate buffer $\mathrm{pH} 9.3$, the derivatization was carried out under the selected conditions. Twenty microliters of this solution were then injected into the HPLC 6 times and analyzed using the optimized method. The results were used to determine the coefficient of variance (\% KV), which was found to be below $2 \%$. The parameters seen were based on the separation between two adjacent peaks (R), the follow-up factor (Tf), peak discharge retention time, the column efficiency (HETP), and the number of theoretical plates $(\mathrm{N})$.

A standard solution of methylsulfonylmethane at a concentration of $4000 \mathrm{ppm}$ was vortexed to homogeneity and $1 \mu \mathrm{L}$ injected into the GC and analyzed using the optimized method.

\section{Validation of analytical methods}

One microliter of $1000 \mathrm{~mL} / \mathrm{mL}$ of hyaluronic acid was placed into a $10 \mathrm{~mL}$ flask and used to produce a 100-ppm solution, which was then used to produce solution of $10,20,30,40$, and $50 \mu \mathrm{g} / \mathrm{mL}$. Samples were then derivatized and $20.0 \mu \mathrm{L}$ of each was analyzed. A plot of peak area $(\mathrm{y})$ versus concentration $(\mathrm{x})$ produced a straight line with a correlation coefficient ( $r$ ) of $\geq 0.999$ (Fig. 1).

Different volumes $(200 \mu \mathrm{L}, 400 \mu \mathrm{L}, 800 \mu \mathrm{L}, 1000 \mu \mathrm{L}, 1200 \mu \mathrm{L}$, and $1500 \mu \mathrm{L}$ ) of the $50,000 \mathrm{ppm}$ methylsulfonylmethane standard solution were each added to $5 \mathrm{~mL}$ volumetric flasks, which were brought to volume using mobile phase solvent and then mixed to produce concentrations of $2000,4000,8000,10,000,12,000$, and $15,000 \mathrm{ppm}$. One microliter of each solution was then injected into the GC and analyzed using the optimized conditions. The data were then used to produce a curve of peak area versus concentration. Result shown in Fig. 2.

Accuracy and precision tests for hyaluronic acid were carried out by analyzing simulated samples, which were produced by adding pure analytes added to the pharmaceutical vehicle. The concentrations used were low, medium, and high, namely, concentrations of $80 \%, 100 \%$, and $120 \%$ of the target concentration. The $100 \%$ sample was made by dissolving $4 \mathrm{mg}$ of the matrix of capsule fillers in a mixture of $20 \mathrm{mg}$ of hyaluronic acid and $32 \mathrm{mg}$ of methylsulfonylmethane. The $80 \%$ concentration was prepared by dissolving $3.2 \mathrm{mg}$ of matrix in a mixture of $16 \mathrm{mg}$ hyaluronic acid and $25.6 \mathrm{mg}$ methylsulfonylmethane. The $120 \%$ concentration was produced by dissolving $4.8 \mathrm{mg}$ of matrix in a mixture of $24 \mathrm{mg}$ hyaluronic acid and $38.4 \mathrm{mg}$ methylsulfonylmethane. All samples were dissolved in $100 \mathrm{~mL} 0.1 \mathrm{~N} \mathrm{HCl}$ then pipette $1 \mathrm{ml}$ and put into a $10 \mathrm{~mL}$ flask. Samples were filtered through a $0.45 \mu \mathrm{m}$ membrane and $300 \mu \mathrm{L}$ of each solution was added to $300 \mu \mathrm{L}$ borate buffer $\mathrm{pH} 9.3$ and $300 \mu \mathrm{L}$ FMOC-Cl $1.5 \mathrm{mM}$ (in acetonitrile) then the sample was filtered using a filter. Twenty microliters of each sample were injected into the HPLC in triplicate and the percent recovery (\% recovery) and \% KV were calculated using calibration curves to determine concentrations. Accuracy was considered acceptable if the percentage of recovery (\% UPK) lays between $98 \%$ and $102 \%$ of target. Precision was considered acceptable if $\% \mathrm{KV}$ was $2 \%$ or less.

Accuracy and precision tests for methylsulfonylmethane were conducted as for hyaluronic acid. The $100 \%$ concentration was produced by dissolving $5 \mathrm{mg}$ of capsule matrix with $5 \mathrm{mg}$ hyaluronic acid and 20 mg methylsulfonylmethane. The $80 \%$ concentration was

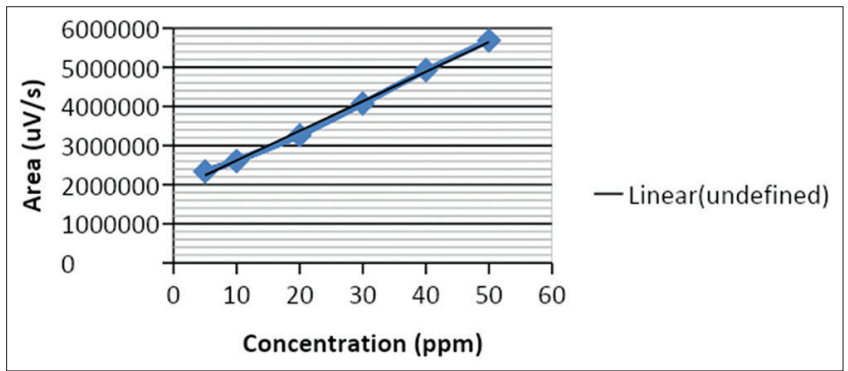

Fig. 1: Calibration Curve for hyaluronic acid

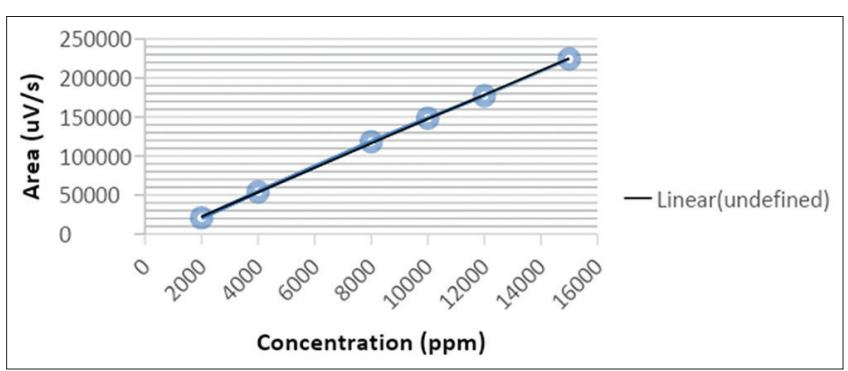

Fig. 2: Calibration curve for methylsulfonylmethane 
produced by dissolving $5 \mathrm{mg}$ of matrix with a mixture of $4 \mathrm{mg}$ hyaluronic acid and 16 mg methylsulfonylmethane. The $120 \%$ concentration was produced by dissolving $5 \mathrm{mg}$ of matrix with $6 \mathrm{mg}$ hyaluronic acid and $24 \mathrm{mg}$ methylsulfonylmethane, methanol was used as a solvent and samples were shaken until dissolved. Each sample was passed through a $0.45 \mu \mathrm{m}$ filter and $1 \mathrm{~mL}$ placed into a $10 \mathrm{~mL}$ volumetric flask, which was filled to volume with n-hexane. One microliter of each sample was analyzed in triplicate, and the recover (\% recovery) and $\% \mathrm{KV}$ calculated using calibration curves to determine concentrations. Accuracy was considered acceptable if the percentage of recovery (\% UPK) lays between $98 \%$ and $102 \%$ of target. Precision was considered acceptable if $\% \mathrm{KV}$ was $2 \%$ or less.

\section{Selectivity}

The standard hyaluronic acid solution was derivatized and then $20 \mu \mathrm{L}$ was injected into HPLC and the chromatograms examined for any differences in retention time between the sample and the standard and to determine whether or not another peak appeared at the hyaluronic acid retention time in the sample solution.

The 40,000 ppm methylsulfonylmethane standard solution of was vortexed to homogeneity and $1 \mu \mathrm{L}$ injected into the GC. The same volume of a matrix solution was next injected and the chromatograms examined to determine whether any matrix components eluted at the same time as methylsulfonylmethane.

\section{RESULTS AND DISCUSSION}

The results of method optimization for hyaluronic acid are summarized in Tables 1-3. Based on the data, a wavelength of $330 \mathrm{~nm}$ with a mobile phase with a ratio $1: 4$ and a flow rate of $1.0 \mathrm{~mL} / \mathrm{min}$ were selected as the optimal conditions because these produced relatively fast retention times, a number of theoretical plates with a relatively small HETP, and a tailing factor close to one.

Results for methylsulfonylmethane analysis optimization are shown in Tables 4-6. This showed that higher initial column temperatures and faster flow rates produced smaller retention times. The initial temperature of the column used was chosen to be $110^{\circ} \mathrm{C}$ with a flow rate of $0.8 \mathrm{~mL} / \mathrm{min}$ because this produced relatively faster retention times, quite a high number of theoretical plates, a relatively small HETP, and a tailing factor of close to one. The $120^{\circ} \mathrm{C}$ temperature was not chosen because it resulted in the peak of the chromatogram at the retention time with the peak of the solvent chromatogram used so that it was feared that the proximity of the two chromatographic peaks could disrupt the chromatogram peak of methylsulfonylmethane compound. The $1.0 \mathrm{~mL} /$ min and $1.2 \mathrm{~mL} / \mathrm{min}$ flow rates were not chosen because they resulted in an unfavorable separation between the substance and solvent peaks.

The conformity tests were carried out to qualify the optimized method by running six consecutive tests under the same conditions. This needs

Table 1: Effect of emission wavelength variations on retention time, peak area, theoretical plate, tailing factor, and HETP of hyaluronic acid derivatives

\begin{tabular}{|c|c|c|c|c|c|c|}
\hline Excitation wavelength (nm) & Emission wavelength (nm) & $\begin{array}{l}\text { Retention time } \\
\text { (min) }\end{array}$ & $\begin{array}{l}\text { Peak area } \\
(\mu V / s)\end{array}$ & $\begin{array}{l}\text { Theoretical } \\
\text { plates }(\mathrm{N})\end{array}$ & $\begin{array}{l}\text { Tailing factor } \\
\text { (Tf) }\end{array}$ & HETP (cm) \\
\hline \multirow[t]{3}{*}{255} & 320 & 5.990 & 2909568 & 892 & 1.219 & 168.14 \\
\hline & 325 & 5.981 & 4819277 & 869 & 1.207 & 172.60 \\
\hline & 330 & 5.999 & 6855595 & 889 & 1.193 & 168.73 \\
\hline
\end{tabular}

Table 2: Effect of variations in the composition on the mobile phase with respect to retention time, peak area, theoretical plate, tailing factor, and HETP of hyaluronic acid derivatives

\begin{tabular}{|c|c|c|c|c|c|c|}
\hline Mobile phase & Mobile phase ratio & Retention time (min) & Peak area $(\mu \mathrm{V} / \mathrm{s})$ & Theoretical plates (N) & Tailing factor (Tf) & HETP (cm) \\
\hline Acetonitrile-acetic & $1: 2$ & 41.312 & 2346676 & 2049 & 0.769 & 7368.27 \\
\hline \multirow{2}{*}{ buffer $\mathrm{pH} 4.2$} & $1: 4$ & 5.999 & 5688541 & 1019 & 1.241 & 147.22 \\
\hline & $2: 3$ & 20.637 & 8123089 & 1626 & 1.563 & 851.63 \\
\hline
\end{tabular}

Table 3: Relationship of flow rate to retention time, peak area, theoretical plate, tailing factor, and HETP of hyaluronic acid derivatives

\begin{tabular}{llllll}
\hline Flow rate $(\mathbf{m L} / \mathbf{m i n})$ & Retention time $(\mathbf{m i n})$ & Peak area $(\boldsymbol{\mu V} / \mathbf{s})$ & Theoretical plates $(\mathbf{N})$ & Tailing factor $($ Tf $)$ & HETP $(\mathbf{c m})$ \\
\hline 0.8 & 7.476 & 2955712 & 1305 & 1.221 & 114.99 \\
1.0 & 5.999 & 3245385 & 1289 & 1.210 & 112.99 \\
1.2 & 5.026 & 3157540 & 694 & 1.217 & 216.29 \\
\hline
\end{tabular}

HETP: Height equivalent to a theoretical plate

Table 4: The relationship between retention time, peak area, number of theoretical plates, column efficiency, resolution, and tailing factor for methylsulfonylmethane at various flow rates and an initial column temperature of column $100^{\circ} \mathrm{C}$

\begin{tabular}{|c|c|c|c|c|c|c|}
\hline Column temperature & $\begin{array}{l}\text { Flow rate } \\
(\mathrm{mL} / \mathrm{min})\end{array}$ & $\begin{array}{l}\text { Retention time } \\
(\text { min) }\end{array}$ & $\begin{array}{l}\text { Peak area } \\
(\mu \mathrm{V} / \mathrm{s})\end{array}$ & $\begin{array}{l}\text { Theoretical plates } \\
\text { (N) }\end{array}$ & $\begin{array}{l}\text { Tailing factor } \\
\text { (Tf) }\end{array}$ & $\begin{array}{l}\text { HETP } \\
\text { (cm) }\end{array}$ \\
\hline \multirow[t]{9}{*}{$100^{\circ} \mathrm{C}$} & \multirow[t]{3}{*}{0.8} & 3.837 & 47392 & 14810.85 & 0.996 & 2.03 \\
\hline & & 3.845 & 34775 & 25638.96 & 0.979 & 1.17 \\
\hline & & 3.826 & 33991 & 13886.27 & 0.982 & 2.16 \\
\hline & \multirow[t]{3}{*}{1.0} & 3.057 & 50043 & 19742.45 & 1.101 & 1.52 \\
\hline & & 3.056 & 50109 & 16555.80 & 1.069 & 1.81 \\
\hline & & 3.076 & 50178 & 11936.14 & 0.825 & 2.51 \\
\hline & \multirow[t]{3}{*}{1.2} & 2.594 & 50164 & 10021.11 & 1.358 & 2.99 \\
\hline & & 2.599 & 42272 & 8338.191 & 1.363 & 3.60 \\
\hline & & 2.621 & 62094 & 9347.068 & 0.924 & 3.21 \\
\hline
\end{tabular}

HETP: Height equivalent to a theoretical plate 
to be done because there will be variations on the results to be obtained so that it can be calculated and proven whether the results obtained are still in accordance with the objectives of the analysis and the applicable provisions or not. The data obtained for the two compounds passed the requirements for repeatability, with the coefficients of variation for both being below $2 \%$ ( $0.1 \%$ for methylsulfonylmethane and $1.11 \%$ for hyaluronic acid). The data shown in Tables 7 and 8.

Linear calibration curves are used to calculate the concentrations of compounds in a sample. A calibration curve for methylsulfonylmethane was produced that contained six points between 2000 and 15,000 $\mu \mathrm{g} / \mathrm{mL}$. The linear equation was $\mathrm{y}=15.596 \mathrm{x}-8673.5$, where $\mathrm{x}$ is the concentration and $y$ is the chromatogram peak area, and the correlation coefficient was 0.9998 (Table 9).

For hyaluronic acid compounds, a 6-point curve between 5 and $50 \mu \mathrm{g} / \mathrm{mL}$ produced a line with the equation $\mathrm{y}=75714 \mathrm{x}-1859406$ and a correlation coefficient of 0.9983 Table 10 .

Accuracy is a value that describes the closeness of test results to the actual level of the analyte in the sample. Accuracy can be defined as the $\%$ recovery, i.e., the percentage of the test result relative to actual content

Table 5: The relationship between retention time, peak area, number of theoretical plates, column efficiency, resolution, and tailing factor for methylsulfonylmethane at various flow rates and an initial column temperature of column $110^{\circ} \mathrm{C}$

\begin{tabular}{|c|c|c|c|c|c|c|}
\hline Column temperature & $\begin{array}{l}\text { Flow rate } \\
(\mathrm{mL} / \mathrm{min})\end{array}$ & $\begin{array}{l}\text { Retention time } \\
\text { (min) }\end{array}$ & $\begin{array}{l}\text { Peak area } \\
(\mu V / s)\end{array}$ & $\begin{array}{l}\text { Theoretical plates } \\
(\mathrm{N})\end{array}$ & $\begin{array}{l}\text { Tailing factor } \\
\text { (Tf) }\end{array}$ & $\begin{array}{l}\text { HETP } \\
(\mathrm{cm})\end{array}$ \\
\hline \multirow[t]{8}{*}{$110^{\circ} \mathrm{C}$} & 0.8 & 3.412 & 50311 & 30283.17 & 0.994 & 0.99 \\
\hline & & 3.386 & 50875 & 26149.43 & 1.002 & 1.15 \\
\hline & & 3.396 & 50656 & 24017.07 & 0.856 & 1.25 \\
\hline & 1.0 & 2.734 & 50240 & 17840.12 & 0.822 & 1.68 \\
\hline & & 2.722 & 50037 & 207320.2 & 0.932 & 0.14 \\
\hline & & 2.722 & 50008 & 20763.31 & 0.976 & 1.44 \\
\hline & & 2.308 & 49178 & 11011.42 & 0.654 & 2.72 \\
\hline & & 2.306 & 51359 & 13757.95 & 0.903 & 2.18 \\
\hline
\end{tabular}

HETP: Height equivalent to a theoretical plate

Table 6: The relationship between retention time, peak area, number of theoretical plates, column efficiency, resolution, and tailing factor for methylsulfonylmethane at various flow rates and an initial column temperature of column $120^{\circ} \mathrm{C}$

\begin{tabular}{|c|c|c|c|c|c|c|}
\hline Column temperature & $\begin{array}{l}\text { Flow rate } \\
(\mathrm{mL} / \mathrm{min})\end{array}$ & $\begin{array}{l}\text { Retention time } \\
\text { (min) }\end{array}$ & $\begin{array}{l}\text { Peak area } \\
(\mu V / s)\end{array}$ & $\begin{array}{l}\text { Theoretical plates } \\
\text { (N) }\end{array}$ & $\begin{array}{l}\text { Tailing factor } \\
\text { (Tf) }\end{array}$ & $\begin{array}{l}\text { HETP } \\
(\mathrm{cm})\end{array}$ \\
\hline \multirow[t]{8}{*}{$120^{\circ} \mathrm{C}$} & 0.8 & 3.077 & 55413 & 20548.17 & 0.957 & 3.41 \\
\hline & & 3.048 & 56478 & 18564.26 & 1.203 & 2.72 \\
\hline & & 3.092 & 52336 & 22654.84 & 0.941 & 1.46 \\
\hline & 1.0 & 2.524 & 58412 & 23154.15 & 1.025 & 1.50 \\
\hline & & 2.486 & 55648 & 26465.26 & 1.335 & 3.00 \\
\hline & & 2.598 & 54852 & 24515.21 & 1.051 & 1.80 \\
\hline & & 1.984 & 52156 & 19354.51 & 1.512 & 2.98 \\
\hline & & 2.012 & 50123 & 23645.35 & 1.320 & 2.87 \\
\hline
\end{tabular}

HETP: Height equivalent to a theoretical plate

Table 7: Conformity test results for the hyaluronic acid system

\begin{tabular}{lllllll}
\hline $\begin{array}{l}\text { Concentration } \\
(\boldsymbol{\mu L} / \mathbf{m L})\end{array}$ & $\begin{array}{l}\text { Retention time } \\
(\mathbf{m i n})\end{array}$ & $\begin{array}{l}\text { Peak area } \\
(\boldsymbol{\mu} \mathbf{V} / \mathbf{s})\end{array}$ & $\begin{array}{l}\text { Theoretical plates } \\
(\mathbf{N})\end{array}$ & $\begin{array}{l}\text { Tailing factor } \\
(\mathbf{T f})\end{array}$ & $\begin{array}{l}\text { HETP } \\
(\mathbf{c m})\end{array}$ & $\begin{array}{l}\text { Average } \\
\text { Standard } \\
\mathbf{d e v i a t i o n}\end{array}$ \\
\hline 20 & 6.463 & 1643597 & 2583 & 0.993 & 58.08 & 1669780 \\
& 6.459 & 1683699 & 2477 & 0.976 & 60.55 & 18605.52 \\
& 6.432 & 1685824 & 2418 & 0.872 & 62.03 \\
& 6.409 & 1651481 & 2317 & 0.838 & 64.73 \\
& 6.391 & 1668269 & 2164 & 0.902 & 69.32 \\
& 1685811 & 2302 & 0.895 & 65.77 \\
\hline
\end{tabular}

HETP: Height equivalent to a theoretical plate

Table 8: Conformity test results for the methylsulfonylmethane system

\begin{tabular}{|c|c|c|c|c|c|c|c|c|}
\hline $\begin{array}{l}\text { Concentration } \\
(\mu \mathrm{L} / \mathrm{mL})\end{array}$ & $\begin{array}{l}\text { Retention time } \\
\text { (min) }\end{array}$ & $\begin{array}{l}\text { Peak area } \\
(\mu V / s)\end{array}$ & $\begin{array}{l}\text { Theoretical plates } \\
\text { (N) }\end{array}$ & $\begin{array}{l}\text { Tailing factor } \\
\text { (Tf) }\end{array}$ & $\begin{array}{l}\text { HETP } \\
(\mathrm{cm})\end{array}$ & Average & $\begin{array}{l}\text { Standard } \\
\text { deviation }\end{array}$ & $\% \mathrm{KV}$ \\
\hline \multirow[t]{6}{*}{4000} & 3.327 & 54266 & 22161.562 & 0.993 & 0.14 & \multirow[t]{6}{*}{54285.17} & \multirow[t]{6}{*}{57.1084} & \multirow[t]{6}{*}{0.11} \\
\hline & 3.336 & 54231 & 21209.208 & 1.294 & 0.14 & & & \\
\hline & 3.347 & 54271 & 13836.078 & 0.976 & 0.22 & & & \\
\hline & 3.338 & 54325 & 15080.732 & 1.32 & 0.2 & & & \\
\hline & 3.338 & 54380 & 22954.957 & 1.296 & 0.13 & & & \\
\hline & 3.347 & 54238 & 17840.273 & 1.193 & 0.17 & & & \\
\hline
\end{tabular}

HETP: Height equivalent to a theoretical plate 
of the sample and should fall within $98-120 \%$ to be acceptable [9]. In this study, this was conducted by producing simulated samples by from mixtures of the two analytes with appropriate pharmaceutical excipients. The mixtures were first prepared, derivatized (for hyaluronic acid) and then analyzed using high-performance fluorescence detector liquid chromatography. Methylsulfonylmethane was prepared then analyzed using by GC. The simulated samples were produced at three different concentrations, namely, $80 \%, 100 \%$, and $120 \%$, which corresponded to hyaluronic acid concentrations of $16 \mu \mathrm{g} / \mathrm{mL}, 20 \mu \mathrm{g} / \mathrm{mL}$, and $24 \mu \mathrm{g} / \mathrm{mL}$, while the simulated methylsulfonylmethane samples contained of $3200 \mu \mathrm{g} / \mathrm{mL}, 4000 \mu \mathrm{g} / \mathrm{mL}$, and $4800 \mu \mathrm{g} / \mathrm{mL}$, respectively. Recovery of methylsulfonylmethane ranged between $100.37 \%$ and $101.50 \%$, while those for hyaluronic acid ranged between $98.59 \%$ and $100.42 \%$, both of which were considered excellent. Result shown in Tables 11 and 12.

Table 9: Calibration curve data, LOD, and LOQ for methylsulfonylmethane

\begin{tabular}{|c|c|c|c|c|c|c|}
\hline Concentration $(\mu \mathrm{L} / \mathrm{mL})$ & Peak area $(\mu \mathrm{V} / \mathrm{s})$ & $y i=a+b x$ & $(y-y i)^{2}$ & $S_{(y / x)}$ & LOD $(\mu \mathrm{g} / \mathrm{mL})$ & $\mathrm{LOQ}(\mu \mathrm{g} / \mathrm{mL})$ \\
\hline 2000 & 20793 & 22518.5 & 2977350.25 & 1730.6455 & 332.9 & 1109.67 \\
\hline 4000 & 54105 & 53710.5 & 155630.25 & & & \\
\hline 8000 & 118345 & 116094.5 & 5064750.25 & & & \\
\hline 10,000 & 148495 & 147286.5 & 1460472.25 & & & \\
\hline 12,000 & 177244 & 178478.5 & 1523990.25 & & & \\
\hline 15,000 & 224373 & 225266.5 & 798342.25 & & & \\
\hline$N=6$ & & & $\Sigma=11980535.5$ & & & \\
\hline
\end{tabular}

LOD: Limit of detection, LOQ: Limit of quantification

Table 10: Calibration curve data, LOD, and LOQ for hyaluronic acid

\begin{tabular}{|c|c|c|c|c|c|c|}
\hline Concentration $(\mu \mathrm{L} / \mathrm{mL})$ & Peak area $(\mu \mathrm{V} / \mathrm{s})$ & $y i=a+b x$ & $(y-y i)^{2}$ & $S_{(y / x)}$ & LOD $(\mu \mathrm{g} / \mathrm{mL})$ & LOQ $(\mu \mathrm{g} / \mathrm{mL})$ \\
\hline 5 & 339912 & 237976 & 0390948096 & 85086.4131 & 3.55 & 11.84 \\
\hline 10 & 603443 & 616546 & 71688609 & & & \\
\hline 20 & 245385 & 373686 & 2209808004 & & & \\
\hline 30 & 74688 & 130826 & 151475044 & & & \\
\hline 40 & 925521 & 887966 & 410378025 & & & \\
\hline 50 & 685411 & 645106 & 624493025 & & & \\
\hline$N=6$ & & & $\Sigma=28958790803$ & & & \\
\hline
\end{tabular}

LOD: Limit of detection, LOQ: Limit of quantification

Table 11: Accuracy and precision data for hyaluronic acid

\begin{tabular}{|c|c|c|c|c|c|c|}
\hline Concentration $(\mu \mathrm{g} / \mathrm{mL})$ & Peak area $(\mu V / s)$ & Measured concentration $(\mu \mathrm{g} / \mathrm{mL})$ & \% Recovery & Average & Standard deviation & KV (\%) \\
\hline \multirow[t]{3}{*}{8} & 2456552 & 7.886864 & 98.59 & 99.03 & 0.7858 & 0.79 \\
\hline & 2464738 & 7.994981 & 99.94 & & & \\
\hline & 2456437 & 7.885345 & 98.57 & & & \\
\hline \multirow[t]{3}{*}{10} & 2619691 & 10.04154 & 100.42 & 100.34 & 0.105 & 0.1 \\
\hline & 2618220 & 10.02211 & 100.22 & & & \\
\hline & 2619478 & 10.03872 & 100.39 & & & \\
\hline \multirow[t]{3}{*}{12} & 2770009 & 12.02688 & 100.22 & 99.51 & 0.6614 & 0.66 \\
\hline & 2758155 & 11.87931 & 98.92 & & & \\
\hline & 2762367 & 11.92595 & 99.38 & & & \\
\hline
\end{tabular}

Table 12: Accuracy and precision data for methylsulfonylmethane

\begin{tabular}{|c|c|c|c|c|c|c|}
\hline Concentration $(\mu \mathrm{g} / \mathrm{mL})$ & Peak area $(\mu \mathrm{V} / \mathrm{s})$ & Measured concentration $(\mu \mathrm{g} / \mathrm{mL})$ & \% Recovery & Average & Standard deviation & KV (\%) \\
\hline \multirow[t]{3}{*}{3200} & 41736 & 3232.207 & 101.01 & 100.96 & 0.5696 & 0.56 \\
\hline & 41416 & 3211.689 & 100.37 & & & \\
\hline & 41983 & 3248.044 & 101.5 & & & \\
\hline \multirow[t]{5}{*}{4000} & 54208 & 4031.899 & 100.8 & 100.65 & 0.1302 & 0.13 \\
\hline & 54136 & 4027.283 & 100.68 & & & \\
\hline & 54107 & 4025.423 & 100.64 & & & \\
\hline & 54031 & 4020.55 & 100.51 & & & \\
\hline & 54191 & 4030.809 & 100.77 & & & \\
\hline \multirow[t]{3}{*}{4800} & 66776 & 4837.747 & 100.79 & 100.86 & 0.0689 & 0.07 \\
\hline & 66879 & 4844.351 & 100.92 & & & \\
\hline & 66832 & 4841.338 & 100.86 & & & \\
\hline
\end{tabular}

Table 13: Quantification data for hyaluronic acid levels in supplements

\begin{tabular}{|c|c|c|c|c|c|c|}
\hline Concentration $(\mu \mathrm{g} / \mathrm{mL})$ & Peak area $(\mu \mathrm{V} / \mathrm{s})$ & Measured concentration $(\mu \mathrm{g} / \mathrm{mL})$ & \% Recovery & Average & Standard deviation & KV (\%) \\
\hline \multirow[t]{3}{*}{10} & 2609213 & 9.9031 & 99.03 & 98.63 & 0.3488 & 0.35 \\
\hline & 2604953 & 9.8469 & 98.47 & & & \\
\hline & 2604378 & 9.8393 & 98.39 & & & \\
\hline
\end{tabular}


Table 14: Quantification data for methylsulfonylmethane levels in supplements

\begin{tabular}{lllllll}
\hline Concentration $(\boldsymbol{\mu g} / \mathbf{m L})$ & Peak area $(\boldsymbol{\mu \nu} / \mathbf{s})$ & Measured concentration $(\boldsymbol{\mu g} / \mathbf{m L})$ & \% Recovery & Average & Standard deviation & KV $(\%)$ \\
\hline 4000 & 53592 & 3992.402 & 99.81 & 99.35 & 0.4010 & 0.40 \\
& 53141 & 3963.484 & 99.09 & & & \\
& 53179 & 3965.921 & 99.15 & & & \\
\hline
\end{tabular}

Precision reflects the reproducibility of results from multiple analyzes of the same material and is measured by $\% \mathrm{KV}$. In general, \% $\mathrm{KV}$ values below $2 \%$ are considered acceptable [9]. Here, the $\% \mathrm{KV}$ was $0.07 \%-$ $0.56 \%$ for methylsulfonylmethane and $0.10 \%-0.79 \%$ for hyaluronic acid, both of which were considered acceptable.

To determine the levels of the two compounds, the samples were prepared containing both. Hyaluronic acid was derivatized using FMOC$\mathrm{Cl}$ first and then analyzed HPLC to yield a sample content of $98.63 \%$. Meanwhile, GC indicated a methylsulfonylmethane content of $99.35 \%$. Result shown in Tables 13 and 14.

\section{CONCLUSION}

The optimum condition for analysis of hyaluronic acid by HPLC was with an excitation wavelength $255 \mathrm{~nm}$ and emission wavelength of $330 \mathrm{~nm}$ and with a mobile phase of acetonitrile-acetate $\mathrm{pH} 4.2$ (1:4) at a flow rate of $1.0 \mathrm{~mL} / \mathrm{min}$. The optimum conditions for the analysis of methylsulfonylmethane by GC were with an initial temperature of column $110^{\circ} \mathrm{C}$ and a subsequent increase of $1^{\circ} \mathrm{C} / \mathrm{min}$ to a temperature of $200^{\circ} \mathrm{C}$, with an injector temperature of $250^{\circ} \mathrm{C}$, a detector temperature of $250^{\circ} \mathrm{C}$, and a nitrogen carrier gas flow rate of $0.80 \mathrm{~mL} / \mathrm{min}$.

The validation conducted here consisted of selectivity, linearity, detection and quantitation limit, and accuracy and precision tests. Both methods fulfilled the applicable criteria with respect to these analyses. For hyaluronic acid, the correlation coefficient was 0.9983 in a concentration range of $5-50 \mu \mathrm{g} / \mathrm{mL}$ and the LOD and LOQ values were $3.55 \mu \mathrm{g} / \mathrm{mL}$ and $11.84 \mu \mathrm{g} / \mathrm{mL}$, respectively. Accuracy values as assessed by recover were $98.59-100.42 \%$ and precision as expressed by $\% \mathrm{KV}$ was below $2 \%$. For methylsulfonylmethane, the correlation coefficient was 0.9998 in the range of $2000-15,000 \mu \mathrm{g} / \mathrm{mL}$ and the LOD and LOQ were $332.90 \mu \mathrm{g} / \mathrm{mL}$ and $1109.67 \mu \mathrm{g} / \mathrm{mL}$, respectively. Accuracy ranged between $100.37 \%$ and $101.50 \%$ and precision was below $2 \%$.
A simulated sample containing both compounds was assessed to contained $98.63 \%$ hyaluronic acid and $99.35 \%$ methylsulfonylmethane.

For further research, hydrolysis of hyaluronic acid compounds is needed to obtain a more sensitive method.

\section{REFERENCES}

1. Cañibano-Hernández A, Saenz Del Burgo L, Espona-Noguera A, Orive G, Hernández RM, Ciriza J, et al. Hyaluronic acid enhances cell survival of encapsulated insulin-producing cells in alginate-based microcapsules. Int J Pharm 2019;557:192-8.

2. Tokita Y, Okamoto A. Hydrolytic degradation of hyaluronic acid. Polym Degrad Stab 1995;48:269-73.

3. Faust HJ, Sommerfeld SD, Rathod S, Rittenbach A, Ray Banerjee S, Tsui BM, et al. A hyaluronic acid binding peptide-polymer system for treating osteoarthritis. Biomaterials 2018;183:93-101.

4. Gocmen G, Gonul O, Oktay NS, Yarat A, Goker K. The antioxidant and anti-inflammatory efficiency of hyaluronic acid after third molar extraction. J Craniomaxillofac Surg 2015;43:1033-7.

5. Lin A, Nguy $\mathrm{CH}$, Shic F, Ross BD. Accumulation of methylsulfonylmethane in the human brain: Identification by multinuclear magnetic resonance spectroscopy. Toxicol Lett 2001;123:169-77.

6. Basu, P, Sunny S, Maier C. Estrogenic and antiestrogenic activities of commercial dietary supplements containing herbal ingredients and isoflavones. Int J Pharm Pharm Sci 2016;8:307-12.

7. Volpi N. Hyaluronic acid and chondroitin sulfate unsaturated disaccharides analysis by high-performance liquid chromatography and fluorimetric detection with dansylhydrazine. Anal Biochem 2000;277:19-24.

8. Vatansever B, Binici B. A quantitative method for the measurement of hydrolyzed type-I collagen protein in dietary supplement sirup using HPLC-SEC-UV technique. J Chem Metrol 2015;1:1-15.

9. Podder AK. Qualitative and quantitative analysis of sildenafil in traditional medicines and dietary supplements. Asian J Pharm Clin Res 2014;7:25-30. 